\title{
REVIEW
}

\section{A Review of Life Cycle Assessment (LCA) of Bioethanol from Lignocellulosic Biomass}

\author{
Poritosh ROY ${ }^{*}$, Ken TOKUYASU ${ }^{1}$, Takahiro ORIKASA ${ }^{2}$, \\ Nobutaka NAKAMURA ${ }^{1}$ and Takeo SHIINA ${ }^{1 *}$ \\ ${ }^{1}$ National Food Research Institute, National Agriculture and Food Research Organization (Tsukuba, \\ Ibaraki 305-8642, Japan) \\ ${ }^{2}$ School of Food, Agriculture and Environmental Sciences, Miyagi University (Sendai, Miyagi 982- \\ 0215, Japan)
}

\begin{abstract}
Liquid biofuels are widely recognized alternatives to fossil fuel not only to combat the global warming potential, but also to reduce the reliance on fossil fuels to facilitate economic development. The production and use of lignocellulosic liquid biofuel have been emphasized because it is highly reproducible and does not compete with food. This study summarizes the LCA studies on lignocellulosic ethanol produced from various biomass resources focusing on energy balance, greenhouse gas (GHG) emission and other impact categories, and the production cost to discuss their potential environmental and socioeconomic impacts. Numerous efforts have been made to evaluate the life cycle of lignocellulosic ethanol with LCA methodologies and deals with feedstock, energy paths, conversion technologies, allocation methods, utilization of by-products etc. to determine the environmental impacts as well as the production cost. The environmental benefits are reported in most of the studies except for few examples. A wide variation was observed in the reported production cost of ethanol, which is dependent on the feedstock, conversion technologies, allocation methods and plant sizes. Onsite enzymes production/purchase appeared to be the main hotspot, demands a vigorous study to improve their productivity and reduce costs. Another promising alternative for compensating production costs seem to be the generation of valuable coproducts and integration of ethanol production processes (ethanol and energy). Reviewed literature indicates that despite the environmental benefits of ethanol produced from lignocellulosic biomass, its economic viability remains doubtful at present, even if highly optimistic assumptions are made for the cost calculation, especially in the case of enzyme. Hence, the biotechnological revolution is must for the sustainability of bioethanol, especially in the field of enzymes and microorganisms. Moreover, the adaptation of innovative technologies and renewable energy policy may help limit costs, but careful consideration of land use changes and soil quality is required to avoid any loss of productivity.
\end{abstract}

\section{Discipline: Biofuel}

Additional key words: GHG emissions, rice straw, enzymatic saccharification

\section{Introduction}

GHG emissions, which have dramatically proliferated due to tremendous energy use, have resulted in global warming, perhaps the most serious problem that humankind faces today. The growing concerns about climate change, rising costs of fossil fuel and the geo-political uncertainty associated with uninterrupted energy supply have motivated individuals, organizations and na- tions to seek clean and renewable substitutes. Liquid biofuels (bioethanol and biodiesel) are widely recognized alternatives to fossil fuel. It is known that renewable energy not only reduces the reliance on foreign oil and improves energy security, but also provides significant environmental benefits and enlarges rural economies ${ }^{69,115}$. The first generation biofuels are produced from food or feed grains, thus compete with food or feed and contribute to higher food prices. Accordingly, the production of second generation biofuels from lignocellulosic biomass

*Corresponding authors: e-mail poritosh@affrc.go.jp, shiina@affrc.go.jp

Received 21 January 2011; accepted 27 May 2011. 
has been emphasized, because it does not compete with food or feed ${ }^{22,47,52,99,141}$.

The life cycle GHG emissions of various forms of bioenergy and their ability to reduce GHG emissions vary widely, and are dependent on land use changes, choice of feedstock, agricultural practices, refining and conversion processes with differing socioeconomic and environmental impacts. It is thus essential to evaluate the environmental impact and the economic feasibility of lignocellulosic-based bioethanols. Environmental awareness influences the way in which legislative bodies such as governments will guide the future development of the lignocellulosic-based ethanol industry. Life cycle assessment (LCA) is a tool for evaluating the environmental effects of a product, process, or activity throughout its life cycle or lifetime, known as a 'from cradle to grave' analysis. Although several researchers have compiled LCA studies of lignocellulosic ethanol to discuss some of the key issues: energy pathways, system boundaries, functional units, allocation methods, utilization of coproducts etc. ${ }^{14,23,24,42,63,77,81,88,111,132}$, some recent advances in LCAs of lignocellulosic bioethanol remain to be reported. Therefore, this study aims to compile recent LCA studies of lignocellulosic bioethanol, and discuss the energetic, environment and socioeconomic aspects of the bioethanol industry.

\section{LCA Methodology}

Although the concept of LCA evolved in the 1960s and there have been several efforts to develop its methodology since the 1970s, it has attracted considerable attention from those engaged in environmental science fields since the 1990s, which has seen the LCA concept promoted, sponsored and developed by various national and international organizations (SETAC: Society of Environmental Toxicology and Chemistry, USEPA: United States Environmental Protection Agency, ISO: International

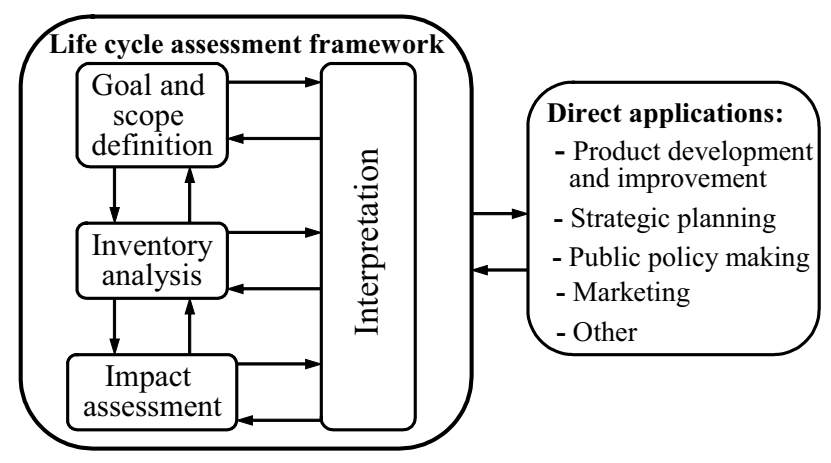

Fig. 1. Stages of an $\mathrm{LCA}^{60}$
Organization for Standardization, ILCAJ: Institute of Life Cycle Assessment, Japan etc.), and LCA practitioners. Consequently, consensus has been achieved on an overall LCA framework and a well-defined inventory methodology $y^{59}$. The method has rapidly developed into an important tool for authorities, industries, and individuals in environmental sciences. The UNEP (United Nations Environment Programme)-SETAC initiative includes methods to evaluate the environmental impacts associated with water consumption and land use ${ }^{65}$. A common methodological framework ("Version Zero") has also been developed by the Global Bioenergy Partnership (GBEP) Task Force on GHG Methodologies that could be applied to the LCA of bioenergy production and compared to the full lifecycle of its fossil fuel equivalent to improve the transparency and acceptance of the results ${ }^{41}$. The LCA methodology consists of four components: Goal definition and scoping, Inventory analysis, Impact assessment and Interpretation. Figure 1 shows the stages of an $\mathrm{LCA}^{60}$. The purposes of an LCA can be: (1) comparison of alternative products, processes or services; (2) comparison of alternative life cycles for a certain product or service; (3) identification of parts of the life cycle where the greatest improvements can be made.

\section{Goal definition and scoping}

Goal definition and scoping defines the purpose of the study, the expected product of the study, system boundaries, functional unit (FU) and assumptions. The system boundary of a system is often illustrated by a general input and output flow diagram. All operations that contribute to the product life cycle, process, or activity fall within the system boundaries. The purpose of the FU is to provide a reference unit to which the inventory data are normalized and its definition depends on the environmental impact category and aims of the investigation. The functional unit is often based on the mass $(\mathrm{kg})$ or volume (L) of the product under study, however the distance $(\mathrm{km})$, land area (ha), energy (MJ) and economic values of products are also used.

\section{Life cycle inventory (LCI) analysis}

This phase includes all inputs and outputs from the processes. The inputs are energy (renewable and non-renewable), water, raw materials etc., while the outputs are products and co-products, and emissions $\left(\mathrm{CO}_{2}, \mathrm{CH}_{4}, \mathrm{SO}_{2}\right.$, $\mathrm{NO}_{\mathrm{x}}, \mathrm{CO}$, etc.), water and soil (total suspended solids: TSS, biological oxygen demand: BOD, chemical oxygen demand: COD, adsorbable organically bound halogens: AOXs, etc.) and solid waste generation. Nowadays, many LCA databases exist and can normally be bought together with LCA software. Data from databases can also be 
used for processes that are not product specific, such as general data on the production of electricity, coal or packaging, although site-specific data are required for product specific data.

\section{Impact assessment}

The life cycle impact assessment (LCIA) aims to understand and evaluate environmental impacts based on inventory analysis, within the framework of the goal and scope of the study. In this phase, the inventory results are assigned to different impact categories, based on the expected types of environmental impacts. Impact categories include global effects (global warming, ozone depletion etc.); regional effects (acidification, eutrophication, photo-oxidant formation etc.); local effects (nuisance, working conditions, effects of hazardous waste, effects of solid waste etc.); biodiversity, water and land use efficiency and impacts on human health (ISO 1025, 2006 $\mathrm{E}^{60}$ ).

\section{Interpretation}

The purpose of an LCA is to draw conclusions that can support a decision or provide a readily understandable LCA result. The inventory and impact assessment results are discussed collectively in the case of an LCIA, or the inventory only in the case of LCI analysis, and significant environmental issues identified for conclusions and recommendations consistent with the goal and scope of the study. This is a systematic technique to identify and quantify, check and evaluate information from LCI and LCIA results, and communicate them effectively. This assessment may include both quantitative and qualitative measures of improvement, such as changes in product, process, and activity design; raw material use, industrial processing, consumer use, and waste management. Cost and profit are the key indicators in decision-making on an investment, while costs are what producers or consumers understand best and an integral part of the decision-making process when identifying improvements of a product, process or activity, hence LCA results are also interpreted in the form of life cycle costing.

\section{LCA studies on lignocellulosic bioethanol}

The life cycle of lignocellulosic ethanol extensively evaluated by using LCA methodologies determines the economic and environmental impacts of different production processes. Figure 2 shows a schematic diagram of ethanol production process using the enzymatic hydrolysis method.

\section{LCA of bioethanol produced from agri-residues}

Agri-residues, known as the most abundant feed-

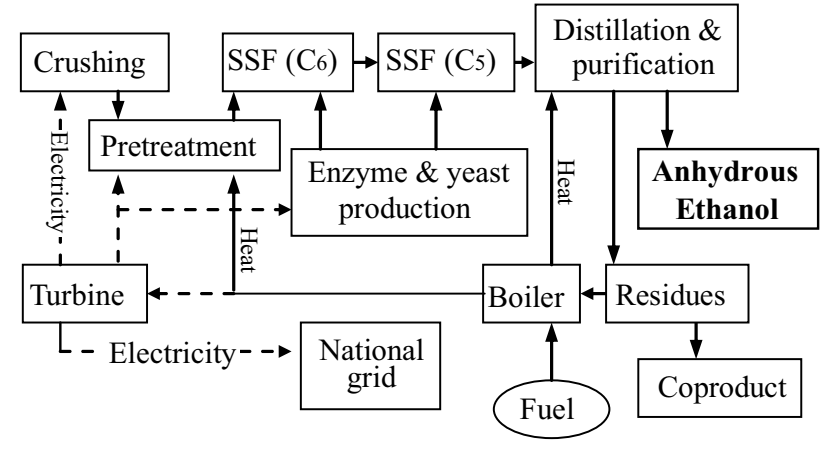

Fig. 2. Schematic diagram of the ethanol production process from lignocellulosic biomass using the enzymatic hydrolysis method

SSF: simultaneous saccharification and fermentation.

stocks for lignocellulosic ethanol, have gained increasing attention as a renewable energy source. LCA methodology has been extensively used to evaluate the life cycle of lignocellulosic ethanol. Several studies noted that lignocellulosic ethanol can improve energy security and contributes significantly to a reduction of GHG emissions $^{37,44,81,115,130,132,137}$. In contrast, the bioenergy system can release more GHG emissions than its fossil alternative when the energy used to feed the biomass conversion process comes from carbon-intensive fossil sources ${ }^{38}$. The reduction in GHG emission is reported to be dependent on feedstocks, conversion technology, utilization of coproducts and allocation methods ${ }^{67,77,78,115,123}$.

Biofuel production is reported to be beneficial in terms of the reduction of non-renewable energy consumption and the global warming impact if biomass from cropping systems is utilized. However, unless additional measures such as planting cover crops are taken, the utilization of biomass for biofuels would also tend to increase acidification and eutrophication, primarily because significant nitrogen and phosphorus related environmental burdens are released from the soil during cultivation $^{70}$. Ethanol produced from the lignocellulosic residues of banana fruit is also reported to be energetically feasible ${ }^{129}$. Stolman ${ }^{119}$ noted that ethanol produced from grass clippings, corn stalks and other plants using future techniques is beneficial. The investigated bioenergy production processes from sugarcane bagasse revealed that the cogeneration option results in lower energy-related emissions (i.e. lower global warming, acidification and eutrophication potentials), whereas the fuel ethanol option is preferred in terms of resource conservation (since it is assumed to replace oil not coal), and also scores better in terms of human and eco-toxicity if assumed to replace lead-bearing oxygenates ${ }^{16}$.

The lignocellulosic (stover) ethanol pathway avoids 
$86-113 \%$ of GHG emissions if E85 is used in fuel flexible vehicles instead of gasoline ${ }^{30,108}$. GHG emissions are reported to exceed $100 \%$, which may be due to the carbon neutrality of biomass and the use of residues. Total fossil energy is also $102 \%$ lower, but emissions of $\mathrm{CO}$, NOx, and SOx increase whereas hydrocarbon ozone precursors are reduced ${ }^{108}$. It is worth noting that biomass combustions are assumed to be carbon neutral in all these studies. Conversely, emissions from stover ethanol are reported to be $65 \%$ lower for the near-term scenario (2010) due to the sharing of emissions with corn grains ${ }^{115}$. Emissions would be about $25-35 \%$ lower than the near-term scenario if the mid-term scenario (2020) is considered. The use of corn stover as a feedstock results in lower GHG emissions relative to conventional corn-grain ethanol ${ }^{70,132}$, although this reduction is dependent on the allocation method used ${ }^{67,70,132}$. The carbon intensity of stover-derived ethanol is reportedly $10-44 \%$ that of gasoline ${ }^{67}$. The corn stover collection emits GHGs after corn harvesting unless equipment capable of performing a singlepass harvest becomes commercially available ${ }^{108}$.

Abiotic resources and ozone layer depletion decrease when gasoline is replaced by stover ethanol fuels (E10 and E85), which is not relevant to the allocation method, however the remaining impacts are larger except the global warming potential (GWP). The GWP reduces when mass/energy allocation is applied, but increases in the case of economic allocation ${ }^{77}$. System boundaries also cause considerable variation in LCA estimates since they not only vary according to start and end points (e.g. well to tank and well to wheel) but also over space and time in a way that can dramatically affect energy and GHG balances ${ }^{16}$. The GWP of the lignocellulosic ethanol plant is noted as significantly (twofold) worse than that of the gasoline refinery, but its improved eco-efficiencies make it superior in terms of abiotic and ozone layer depletion potentials ${ }^{79}$. In contrast, GHG savings from ethanol and Ethyl Tertiary Butyl Ether (ETBE) blending are reported to be positive, even taking into consideration the modification of the refinery sector included ${ }^{29}$.

Uihlein and Schebek ${ }^{126}$ concluded that bio-based products and fuels from straw may also be associated with environmental disadvantages due to, e.g. land use or water eutrophication. The environmental impacts predominantly result from the provision of hydrochloric acid and, to a smaller extent, from the provision of process heat. The optional acid and heat recoveries yield environmental impacts that are approximately $41 \%$ lower than those of the fossil counterparts. LCA of lignocellulosic (straw, waste wood and other agricultural waste) ethanol produced by an enzymatic hydrolysis process shows that El0 improves the environmental performance in GHG emissions if the energy required to generate the process steam is derived from biomass rather than fossil fuel for pretreatment of feedstock, but has inferior performances in terms of acidification, eutrophication, winter smog, summer smog, carcinogenic substances, heavy metals, ozone layer depletion and solid waste ${ }^{38}$. The net energy ratios (output energy divided by input energy from fossil fuels) of ethanol production systems from high yield rice plants are also reported to be positive, where rice and its residues are used ${ }^{73,98}$. Koga and Tajima ${ }^{73}$ also noted that whole rice plant-based ethanol production systems improve energy efficiency and reduce GHG emission, because straw removals notably mitigate $\mathrm{CH}_{4}$ emissions from the paddy field. The use of straw for energy (CHP: combined heat and power) in bioethanol production from wheat grains has significant benefits in terms of reduced global warming and the use of non-renewable energy, but the eutrophication and atmospheric acidification impact categories were slightly unfavorable in some cases $^{39}$. Cherubini and Ulgati ${ }^{25}$ noted that the use of agricultural residues in a biorefinery saves GHG $(50 \%)$ and reduces demand for fossil fuels $(80 \%)$, where the best management practices are employed. However, biomass harvest rates must be carefully established.

Although agri-residues are identified as abundant lignocellulosic biomass resources, there is debate regarding the actual amounts of residues which could be removed from arable soils with no loss of quality, as well as the potential tradeoffs in the overall energy chain compared to the use of fossil energy sources. Gabrielle and Gagnaire $^{39}$ noted that straw (wheat straw) removal had little influence on environmental emissions in the field, and incorporating it in soil resulted in sequestration of only $5-10 \%$ of its $\mathrm{C}$ in the long term. It is also noted that a certain portion of crop residues can be removed to produce bioethanol without degrading the soil quality, depending on the season, location, tillage and soil types ${ }^{87,94}$. Selecting residues that contain relatively high levels of available cellulose and hemicellulose for removal or returning suitable crop residues that are rich in refractory compounds may increase the scope for removal of crop residues for ethanol production ${ }^{94}$. Sheehan et al. ${ }^{109}$ state that up to $60 \%$ of the stover can be collected and converted to fuel ethanol, however Blanco-Canqui and Lal ${ }^{13}$ suggested a stover removal rate as low as $25 \%$, beyond which soil fertility and structural stability would be negatively affected. Graham et al. ${ }^{46}$ noted that in current agricultural practice, only $28 \%$ of the stover is harvested, and the rest is left in the field for soil fertility. Although lignocellulosic biomass is reported to be the most promising feedstock considering its great availability and low cost, the large-scale commercial production of fuel bioethanol 
from lignocellulosic materials has yet to be implement$\mathrm{ed}^{4,62}$, due to challenges and obstacles such as cost, technology and environmental issues needing to be overcome for the commercial production of lignocellulosic ethanol $^{55,122}$.

\section{LCA of bioethanol from energy crops, woody biomass and forest residues}

Presently, the contribution of energy crops as a proportion of total biomass energy is relatively small, but it is set to grow in the near future. The majority of LCA studies noted that bioenergy from energy crops reduces GWP and fossil energy consumption when the most common transportation biofuels are used to replace conventional diesel and gasoline $\mathrm{e}^{14,26,50,102,110}$ in all but a few studies $^{92,104}$. In contrast, other environmental aspects such as acidification and eutrophication increase ${ }^{26}$, and including land use change effects in GHG balances, biofuels substituting fossil fuels may lead to increased negative impacts $^{104}$. Pimentel and Patzek ${ }^{92}$ noted that ethanol production from switchgrass and woody biomass requires 50 and $57 \%$ more fossil energy than the ethanol fuel produced, respectively. In contrast, Cherubini et al..$^{23}$ believed these limitations could be partially overcome by developing second generation biofuels, produced from various lignocellulosic non-food crops and residues.

Estimated GHG emissions from cellulosic ethanol were $94 \%$ lower than those of gasoline, while genetic and agronomical improvement may further enhance the energy sustainability and biofuel yield of switchgrass ${ }^{102}$. Switchgrass fields are reported to be near-GHG neutral depending on the agricultural inputs (mainly $\mathrm{N}$ fertilization) and subsequent biomass yields. The use of ligneous biomass residue for energy at a cellulosic biorefinery is the main key to reducing GHG emissions rather than biofuels from annual crops, where processing energy is derived from fossil fuels ${ }^{35}$. Spatari et al. ${ }^{115}$ noted that emissions from energy crop (switchgrass) ethanol were $57 \%$ in the case of the near-term scenario (2010) and lower for an E85-fueled automobile compared to gasoline, on a $\mathrm{CO}_{2}$ equivalent per kilometer basis. Emissions could be $25-35 \%$ lower than those of the near-term scenario if the mid-term scenario (2020) were considered. Net energy gains per hectare of biofuels are affected by the crop yield, conversion rate, and energy inputs required to produce, deliver and process feedstock. The yearly net energy gain is reported to be greater in the case of field scale trials on marginal land than low-input switchgrass grown in small plots ${ }^{102}$.

González-García et al. ${ }^{45}$ assessed the environmental performance of bioethanol produced from poplar biomass considering three ethanol applications (E10, E85 and E100), addressed the impact potentials per kilometer driven by a mid-size passenger car, and compared it with gasoline. The authors noted that fuel ethanol derived from poplar biomass may help ease the exacerbation of global warming, and depletion of abiotic resources and the ozone layer by up to 62,72 and $36 \%$, respectively. Conversely, acidification and eutrophication would intensify. Tilman et al. ${ }^{123}$ noted that biofuels derived from lowinput high-diversity (LIHD) mixtures of native grassland perennials can provide more usable energy, greater GHG emission reductions, and less agri-chemical pollution than that of corn grain ethanol. LIHD biofuels are carbon negative because net ecosystem carbon dioxide sequestration ( $4.4 \mathrm{t} / \mathrm{ha} /$ year of carbon dioxide in soil and roots) is reported to be greater that the release during biofuel production $(0.32 \mathrm{t} / \mathrm{ha} /$ year). LIHD biofuels can also be produced on agriculturally degraded lands and thus neither displace food production nor cause any loss of biodiversity via habitat destruction.

Switchgrass is reported to be effective at storing soil organic carbon (SOC), not just near the soil surface, but also at depths below $30 \mathrm{~cm}$ where carbon is less susceptible to mineralization and $\operatorname{loss}^{76,102,136}$. Haney et al.$^{54}$ noted that perennial grass systems had higher SOC and water extractable organic C (WEOC) than the annual corn system. Among perennial grass systems, switchgrass had the lowest SOC and WEOC. Nitrogen leaching is reported to be less for switchgrass than corn, but greater than in alfalfa-corn cropping systems ${ }^{128}$. Monti et al. ${ }^{86}$ analyzed the energy crops (switchgrass, giant reed and cynara) production in terms of energy and hectares, and compared them with conventional wheat and maize rotation. This study concluded that on average, $50 \%$ lower environmental impacts can be achieved by substituting conventional rotation with perennial crops. The benefits are reportedly dependent on biomass yield and the preference to a specific energy crop strongly depends on weighting sets that may change considerably in terms of space and time.

It is also concluded that the economic and environmental aspects of high yield crop production systems are not necessarily conflicting, whereas under or over supply of nitrogen fertilizers leads to a decline in resource use efficiency ${ }^{18,19,51}$. Pedersen et al. ${ }^{90}$ reveal that in the USA, some long-term breeding of switchgrass has achieved large yields and may begin to contribute significantly to biofuel production. Genetically modified (GM) herbicide tolerant energy crops (sugar beet) are reported to be less harmful to the environment and human health than growing conventional crops, largely due to lower emissions from herbicide manufacture, transport and field operations $^{10}$. These studies indicate that the social and environmental co-benefits, including carbon sequestration 
opportunities, will be drivers of future energy cropping uptake, although they must also be ecologically sustainable, environmentally acceptable and economically competitive with fossil fuels ${ }^{110}$.

\section{Land, water and other approaches in LCA of bioethanol}

The global population continues to grow geometrically, exerting great pressure on arable land, water, energy and biological resources to provide an adequate food supply while maintaining the ecosystem. The availability of land on which to grow biofuel crops without affecting food production or GHG emissions from land conversion is limited, hence land use efficiency should be maximized to achieve climate change goals. Although lignocellulosic ethanol supply chains are considered feasible for making GHG savings relative to gasoline, an important caveat is that if lignocellulosic ethanol production uses feedstocks that cause indirect land-use change, or other resulting significant impacts, any benefit may be greatly offset ${ }^{113,114}$. The effects of land use changes were noted as having a significant influence on the final GHG balance (about 50\%) ${ }^{25}$.

Several studies also noted that converting croplands or grasslands to produce energy crops may actually lead to an increase rather than fall in GHG emissions ${ }^{34,104}$. Brandão et al. ${ }^{17}$ studied the different land use systems used for energy crops and noted that Miscanthus is the optimal choice in terms of GHG emissions and soil quality compared to oilseed rape, short-rotation coppice willow and forest residues, but performed worse in the categories of acidification and eutrophication, while oilseed rape showed the worst performance across all categories. Stephenson et al. ${ }^{117}$ reported that if willows are grown on idle arable land in the UK, or in Eastern Europe, and imported as wood chips into the UK to produce ethanol, this saves about $70-90 \%$ of GHG emissions compared to fossil-derived gasoline on an energy basis. In contrast, Searchinger et al. ${ }^{104}$ estimated GHG emissions from landuse changes by using a global agricultural model and noted that corn-based ethanol, instead of achieving $20 \%$ savings, nearly doubles GHG emissions over 30 years and increases GHGs for 167 years. Biofuels from switchgrass also increase emissions by $50 \%$, if grown on U.S. corn lands. It is also reported that the bioelectricity pathway outperforms the cellulosic ethanol across a range of feedstocks, conversion technologies, and vehicle classes; producing $81 \%$ more transportation kilometers and $108 \%$ more emission offsets per unit area of cropland than cellulosic ethanol ${ }^{21}$.

Based on the ecological footprint perspective, Stoeglehner et al. ${ }^{118}$ noted that biofuels will only be able to contribute to a certain - maybe relatively limited - extent, to an overall sustainable energy supply that will vary widely between regions, and the sustainability of biofuel production depends on the amount of land available. It is reported that direct land use changes, the choice of calculation methods, utilization of coproducts and the technical design of production systems all impact on GHG balances and eutrophication for all biofuels ${ }^{15}$. The enhanced demand for biofuel crops under the EU Biofuel Directive has a strong impact on agriculture at a global and European level, while the incentive to increase production in the EU tends to increase land prices and farm income there and in other regions ${ }^{6}$.

The sustainability of biofuels depends on the selection of land on which feedstocks are grown. Several competing factors need to be balanced, such as changes in land use (clearing tropical forests or using peatlands for crop cultivation) to negate any of the intended future climate benefits, and impacts on biodiversity. In addition, developments in the agricultural sector for food and non-food crops will have important implications for water usage and its availability. The opportunity costs and rebound effects of land use changes must be addressed when considering any decision to assign land to biofuel feedstocks ${ }^{91}$. Although biomass residues have been identified as a potential feedstock for bioenergy, the global mature forest area will decrease by $24 \%$ between 1990 and 2100 , due to both population growth and wood biomass demand in developing regions, and may even disappear by 2100 in some developing regions, such as Centrally Planned Asia, Middle East and North Africa, and South Asia ${ }^{139}$.

The gross water consumption in the lignocellulosic ethanol production processes are reported to be $28-54 \mathrm{li}-$ ters per liter of ethano ${ }^{95}$. The high water consumption results from the process water used in the $\mathrm{Ca}(\mathrm{OH})_{2}$ pretreatment, washing of solids prior to enzymatic hydrolysis. However, water consumption is reported to be only $0.3 \mathrm{~L}$ per liter of ethanol produced from agri-residues (corn stover or wheat straw), because the water requirement for crop production was attributed only to grain $\mathrm{s}^{12}$. Ethanol produced using a biochemical or thermochemical conversion process is expected to reduce GHG and air pollutant emissions, but involve similar or potentially greater water demands and solid waste streams than conventional ethanol biorefineries. Despite current expectations, significant uncertainty remains regarding how well next-generation biofuels will fare in terms of different environmental and sustainability factors when produced on a commercial scale in the U.S. ${ }^{132}$. Although ethanol production consumes huge amounts of water, its impact on water resources is seldom included. The land to man ra- 
tio in developing countries is not as favorable as in developed countries, with far scarcer land resources creating serious problems in land resources management and possibly resulting in land degradation in such developing countries. The use of bioenergy also involves environmental challenges, for instance increased mono-cropping practices and greater fertilizer and pesticide use, which may jeopardize water and soil quality. Perhaps the main concern over land use change is the risk of large areas of natural forests and grasslands being converted to energy crop production, which would not only threaten biodiversity and ecosystems, but also result in a possible increase in GHG emissions.

\section{Cost analysis}

Costs are what producers, or consumers understand best and an integral part of the decision-making process when identifying potential improvements of a product, process, or activity, hence the use of life cycle costing (cost analysis of the entire life cycle) as a decision support tool in the bioethanol industry. The production cost of ethanol is dependent on both technical and economic parameters, such as the cost of feedstocks, choice of feedstocks, energy consumption, conversion technology and efficiency, and the value of coproducts ${ }^{1,2,4,5,31,82,135,137}$. The production cost of lignocellulosic bioethanol is reported to be considerably higher than the market price of gasoline $\mathrm{f}^{5,58,79,89,96,135}$. Vadas et al. ${ }^{128}$ noted that net energy production per hectare is greater for switchgrass than that of alfalfa-corn cropping systems, but may not return the potential income to farmers that alfalfa-corn could. The costs of cellulase and capital are the major expenses when producing lignocellulosic bioethanol ${ }^{95}$, while industrial cellulase contributes about $40-55 \%$ of the enzymatic cellulosic ethanol production cost. The estimated costs of producing ethanol from lignocellulosic residues (verge grass, wheat milling residues and woody energy crop/ willow) are $0.75-0.99 € / \mathrm{L}$. The authors noted that the cellulase cost (assumed $0.51 € / \mathrm{L}$ ) would have to be reduced at least tenfold and the capital cost by $30 \%$ to achieve ethanol production costs comparable to those of ethanol from starch crops. It is also noted that the production cost of cellulosic ethanol depends on feedstocks and their composition as well as plant capacity. The estimated production cost varies from about $0.38-0.48$ US\$/L (plant size: feedstocks consumption is $2000 \mathrm{t}$ / day $)^{58,105}$. For the same plant capacity the production cost of ethanol from corn stover is reported to be $0.71-0.87$ US $\$ / \mathrm{L}$ dependent on the assumed scenarios ${ }^{31}$. The production cost is noted to be $0.56-0.77$ US\$/L depending on the feedstock and plant sizes ${ }^{43}$. The simulated produc- tion cost of ethanol is reported to be $0.94-1.20 \mathrm{US} \$ / \mathrm{L}$ which depends on the ethanol yield ${ }^{72}$.

The economic viability, GHG emission and economic performance of lignocellulosic ethanol under extreme weather conditions are also reported to be dependent on the availability of feedstock (weather condition) and the use of single or multiple feedstocks ${ }^{74}$. Wingren et al. ${ }^{96}$ noted that the production cost is also dependent on enzymatic processes. The cost of ethanol produced from softwood based on simultaneous saccharification and fermentation (SSF), and separate hydrolysis and fermentation (SHF) are reported to be 0.57 and $0.63 \mathrm{US} \$ / \mathrm{L}$, respectively. The main reason for SSF being lower was the lower capital cost and the overall higher ethanol yield. Major economic improvements in both SSF and SHF could be achieved by boosting income from the solid fuel coproduct, reducing energy consumption and recycling process streams. A techno-economic evaluation of the spruce-toethanol process, based on $\mathrm{SO}_{2}$-catalysed steam pretreatment followed by simultaneous saccharification and fermentation with various process configurations, achieved an ethanol cost of about $0.38-0.50 € / \mathrm{L}$. Anaerobic digestion of the stillage with biogas upgrading was a demonstrably favorable option in terms of both energy efficiency and ethanol production $\operatorname{cost}^{8,9}$ and the contribution of enzyme is reported to be $0.04-0.05 € / \mathrm{L}^{9}$.

Ballerini et al. ${ }^{5}$ concluded that technical and economic optimization of the pretreatment step, the total substitution of lactose by pentose hydrolysate as the main carbon source for enzyme production, and the recycling

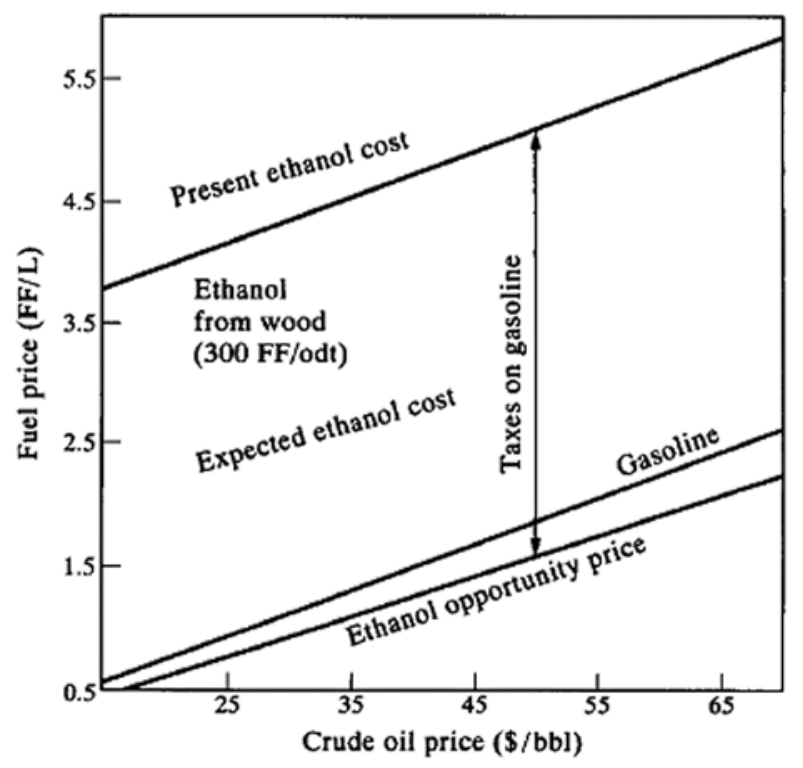

Fig. 3. Economics of ethanol production from wood in France $^{5}$ FF: French Franc, odt: oven dry ton, bbl: barrel 
of a fraction of the enzyme, the incorporation of pentose in ethanol fermentation, and the utilization of by-products all reduce the production cost of lignocellulosic ethanol. The authors also noted that since ethanol from biomass is tax-exempted, it could compete with gasoline assuming a crude oil price of around US\$50 (Fig. 3). In contrast, it is noted that with current technology, the production cost of cellulosic ethanol $(0.75 \$ / \mathrm{L})$ is almost double compared to the market price of oil $(0.48 \$ / \mathrm{L})$ and much of the optimism surrounding cellulosic ethanol has faded $^{107}$. The externality (environmental and health) cost of bioethanol is also reported to be dependent on the feedstock ${ }^{75}$.

Hamelinck et al. ${ }^{53}$ stated that the combined effect of higher hydrolysis-fermentation efficiency (to 68\%), lower specific capital investments, increased scale (5 times) and lignocellulosic and woody biomass feedstock costs reduced to about $67 \%$ could slash ethanol production costs to $59-40 \%$ of the current level in $10-20$ years or more. The production cost is reported to be slightly higher for wood-produced ethanol compared to that of switchgrass $^{92}$. The production costs of bioethanol from energy crops vary widely due to the complex characteristics of the resource, their site specificity, national policies, labor costs and efficiency of the conversion technologies, but are expected to decline over time $e^{110}$ and it is noted to have clear socioeconomic benefits ${ }^{50}$.

The coproduct revenue and utilization of the excess solid residue for heat and power production had a considerable effect on the process economics, and improved ethanol yield and reduced energy demand resulted in significant production cost reductions $(0.41-0.50 € / \mathrm{L})^{100,101}$. Sassner et al. ${ }^{101}$ also concluded that the utilization of pentose fractions for ethanol production helped achieve good process economy, especially in the case of Salix or corn stover. It is also noted that ethanol produced from softwood and sold as a low percentage blend with gasoline could ultimately be cost competitive with gasoline without requiring subsidy, but that production from straw would generally be less competitive ${ }^{114}$. Despite the environmental benefits of ethanol produced from coppice willow, its economic viability remains doubtful at present ${ }^{117}$. The author argued that the production cost could be reduced significantly if the willow were altered by breeding to improve its suitability for hydrolysis and fermentation. A techno-economic assessment of lignocellulosic ethanol also revealed that commercial success of pilot plants (0.3-67 MW) remains pending, although cost-competitive ethanol can be produced with efficient equipment, optimized operation, cost-effective syngas cleaning technology, inexpensive raw material with low pretreatment cost, high performance catalysts, off-gas and methanol recycling, an optimal systematic configuration and heat integration, and a high value by-product with a plant capacity of $200 \mathrm{MW}^{56}$. The estimated cost of ethanol from wood varies between $0.50-0.76$ US $\$ / L$ depending on the plant capacity ${ }^{3,40,97}$.

The reported enzyme cost of lignocellulosic ethanol varied widely, with the on-site enzyme production/purchase cost reported to date perhaps the most contentious or dubious estimation/prophecy. In the USA, the costs associated with dedicated cellulase production are reported to be $0.1-0.5 \mathrm{US} \$ /$ gal ethanol ${ }^{1,2,80,135}$. It is also predicted that in future, less cellulase will be necessary, due to increased specific enzyme activity: threefold in 2005 and tenfold in $2010^{135}$. The present enzyme production cost is estimated as $265 \$ / \mathrm{m}^{3}$ (1 \$/gal), but with recent investments and continuous research efforts, this value may drop to $130 \$ / \mathrm{m}^{3}(0.5 \$ / \mathrm{gal})$ by $2010^{20,103}$. The most astonishing prediction seems to be of enzyme productivity: 600-2000 FPU/g glucose+Xylose between 2005 to $2010^{135}$, which is subject to considerable doubt. Presently, the enzyme productivity achieved is reported to be 333 FPU/g glucose (NFRI, 2010; unpublished data). Conversely, the cost of cellulase is reported to be $0.51 € / \mathrm{L}^{95}$. The reported enzyme cost (production/purchase) is Canadian dollar (CAD) 12/million FPU (enzyme loading: 10 FPU/g cellulose $)^{48}$. These studies reported a wide variation of the cost of cellulase, hence the ethanol.

The key objective of an LCA study is to provide as complete a portrait as possible of energy consumption, environmental impacts, economic viability and their rebound effects and hence enable effective planning for a sustainable society. Reviewed LCA studies were ridiculous to compare due to deferring system boundaries, objectives and functional units. The main categories discussed in the LCA studies of lignocellulosic bioethanol were energy balance and GHG emissions, soil quality, land and water use, and production cost. Table 1 represents a brief summary of the LCA studies concerning energy balance and GHG emissions, soil quality and land and water use. Table 2 shows a summary of the reported cost of cellulase and the production cost of ethanol produced from cellulosic biomass by different authors.

\section{Discussion}

In recent years, the production of biofuels (bio-ethanol and bio-diesel) has been increasing rapidly, affecting virtually all aspects of field crop sectors, ranging from domestic demand and exports to price and the allocation of land area among crops. Adjustments in the agricultural sector are already underway, given the growing interest in renewable energy sources to reduce environmental 


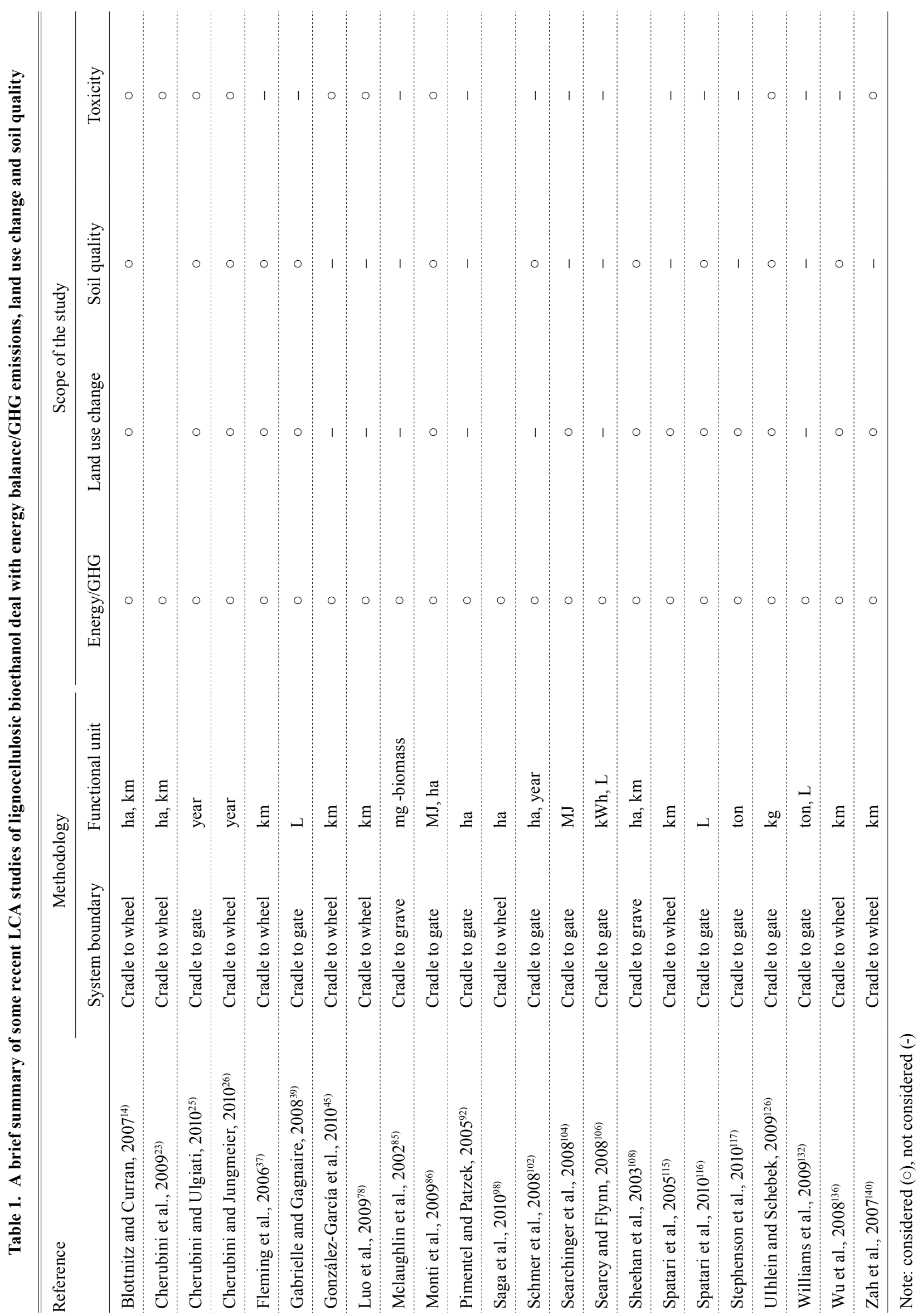




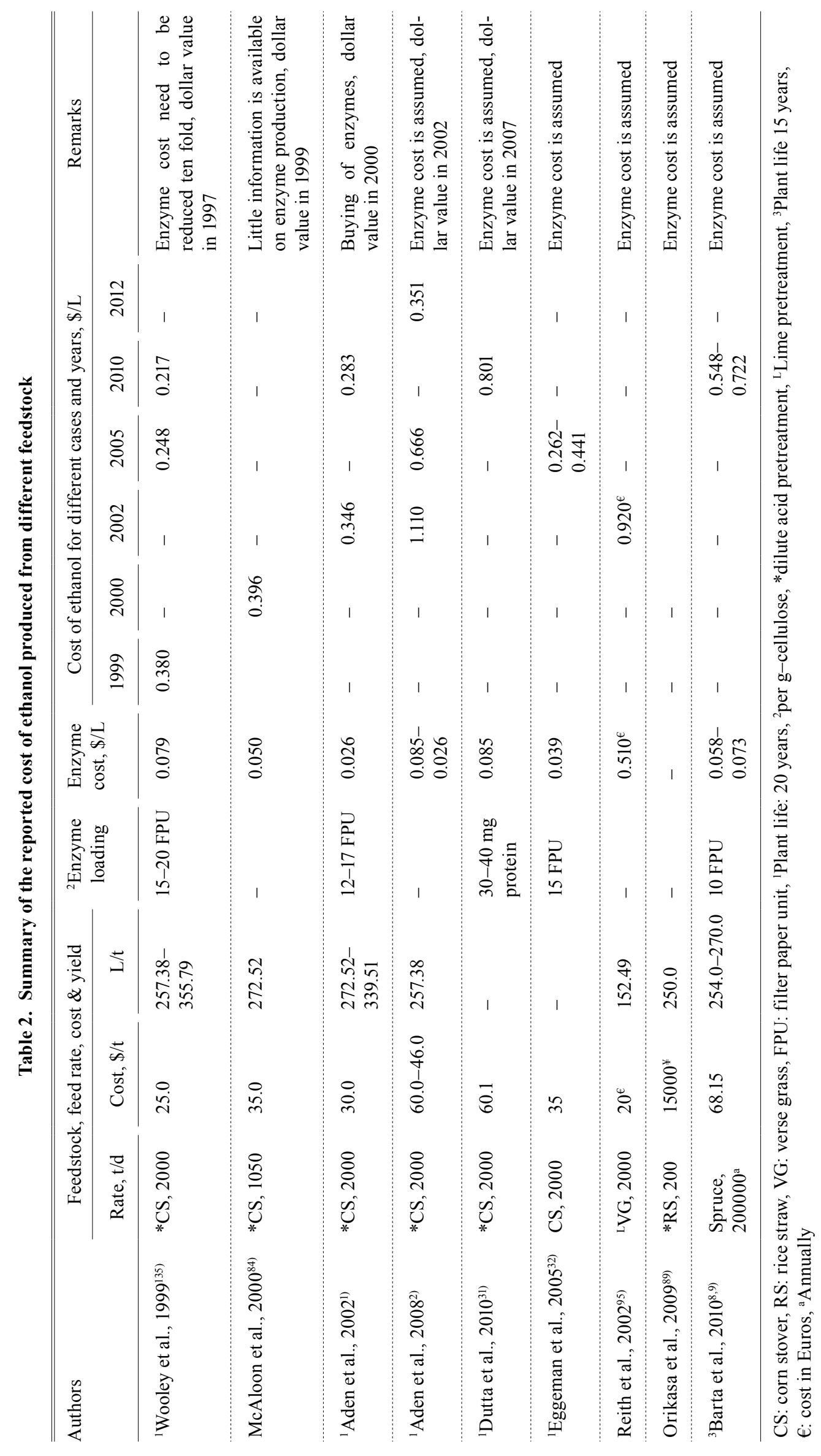


pollution and dependency on foreign oil, which might affect biodiversity, soil erosion and its quality. Hence, the interpretation should be based on agricultural intensity, socioeconomic aspects, land and water use and soil quality as well as the environmental and socioeconomic impacts of lignocellulosic ethanol.

The rate of decomposition of soil organic matter, both that originally in the soil and that added through crop residue mulch, is reported to be higher in the tropics than in temperate climates. Jenkinsoin and Ayanaba ${ }^{61}$ reported that 12 tons biomass/ha/year was insufficient to meet the ecosystem demand for maintenance or sequestration of the SOC pool in Ibadan, Nigeria. The amount of corn (Zea mays L.) stover needed to maintain SOC, which is responsible for favorable soil properties, was reported at 5.25-12.50 t/ha/year. Johnson ${ }^{64}$ concluded that the minimum above-ground source carbon (MSC) requirement was $2.5 \pm 1.0$ ton/ha/year for moldboard plow sites and $1.8 \pm 0.44 \mathrm{ton} / \mathrm{ha} / \mathrm{year}$ for non-tilled and chisel plowed sites which is equivalent to 6.25 and 4.50 ton stover/ha/year, respectively. Above-ground biomass production is reported to be 5.46 and 10.00 ton/ha for paddy and corn, respectively ${ }^{64,89}$. It is predicted that removal of corn stover from soil could decrease nitrogen-related emissions and also reduce the annual accumulation rates of $\mathrm{SOC}^{71}$. These estimates indicate that the need for stover to maintain SOC, and thus productivity, are a greater constraint to an environmentally sustainable cellulosic feedstock harvest than that needed to control water and wind erosion ${ }^{131}$. In contrast, Sheehan et al ${ }^{108}$ noted that SOC drops slightly in the early years of stover collection but remains stable over the 90 -year time frame.

The various cultivation practices and ethanol production technologies have different impacts. GHG emissions in agriculture, for example, are largely determined by the emission of nitrous oxide or methane whereas the ethanol production process by $\mathrm{CO}_{2}$ is a factor of electricity generation and fermentation. The production of the enzyme used for hydrolysis requires substantial fossil fuel or electricity for air compression, which also generates considerable $\mathrm{CO}_{2}$ in the chain ${ }^{78}$. The recalcitrance of lignocellulosic biomass still renders the proposed processes complex and costly, but there are grounds for optimism: the application of newly engineered enzyme systems and the construction of inhibitor-tolerant industrial yeast strains, combined with optimized process integration, promises significant improvements ${ }^{83}$. The production of ethanol from lignocellulosic materials requires considerable research and development before reaching an economically viable stage. If crop residues are utilized in the ethanol industry, there should also be careful consideration to maintain soil organic carbon to avoid a decline in productivity and soil.

The LCA results of lignocellulosic ethanol are more sensitive to the changes in parameters related to the biomass and ethanol yield. The cultivation practices, enzyme and ethanol production technologies are the main processes, which could significantly affect environmental impacts. Although the biofuel industry provides significant environmental benefits and enlarges rural economies $^{68,91,115}$, its negative impacts are also reported ${ }^{27,28}$. Mandatory blending pushes up petrol prices as feedstock are not profitable to use in fuel production given current technologies ${ }^{6}$. The production of biofuels from lignocellulose is also limited by the amount of plant matter which can be sustainably produced and harvested ${ }^{121}$. The cultivation of bioenergy and biofuel crops affects biodiversity more directly, both positively and negatively. The changes to policy and land use should be addressed, not simply in terms of species abundance at field level, but also changes to landscape diversity, potential impacts on primary and secondary habitats and potential impacts on climate change ${ }^{36}$. It is also reported that the production of biofuels is often not competitive with oil unless subsidized or benefiting from tax credits that offset those already provided to the alternatives ${ }^{134}$.

A survey in the USA revealed that only $17 \%$ of Iowa's farmers currently have interest in harvesting their corn stover; though $37 \%$ are undecided. Farmers who anticipate the negative impacts of corn stover removal on environmental quality tended to be less interested in harvesting $\mathrm{it}^{125}$. Farmer participation would be the main key in harvesting/supplying corn stover/crop residues for lignocellulosic ethanol in the near future. Jensen et al. ${ }^{62}$ investigated U.S. energy policy and revealed that it focused more on the producer stage of the lignocellulosic ethanol life cycle than the landowner or consumer stages, despite the need to reflect the requirements of land owners and consumers in future renewable energy policy to ensure steady feedstock supplies and the development of a strong lignocellulosic ethanol industry. Farrell et al. ${ }^{35}$ suggested that the large-scale use of ethanol for fuel would certainly require cellulosic technology. Tilman et al. ${ }^{124}$ noted that the biofuels policy in the USA has become increasingly polarized, and that political influence seems to be trumping science. Harnessing the best available science, continually updated information should be used to evaluate the extent to which various biofuels achieve their multiple objectives. The development of rigorous accounting rules is urged to assess the impacts of biofuels on the efficiency of the global food system, GHG emissions, soil fertility, water and air quality, and biodiversity ${ }^{36}$ should be considered in the full life cycle of biofuels production, transformation, and combustion ${ }^{124}$. The ISO series rec- 
ommends using methods that reflect the physical relationship, e.g. the mass and energy content or using other relevant variables to allocate, such as the economic value of products, which is similar to the cost allocation methods in managerial accounting ${ }^{49}$. The ecoinvent default allocation includes differentiated allocation factors based on physical-causal relationships, common physical parameters (mass or heating values), and/or the economic values of the valuable outputs of the multi-output process $^{66}$. However, Singh et al. ${ }^{111}$ was against the use of allocation based on economic value. A common methodological framework was developed by the GBEP that could be applied to the LCA of bioenergy production and compared to the full life cycle of its fossil fuel equivalent to improve the transparency and acceptance of the results.

The GBEP is also promoting bioenergy activities, especially in developing countries. Lignocellulosic biomass comes from energy crops/grass, wood, agricultural residues and by-products, and forestry residues. Sukumaran et al. ${ }^{120}$ concluded that despite the abundant biomass residues generated in India as agro-and forest residues, the only feasible feedstock among them would be the crop residues due to problems in terms of collection and logistics. The residues from major agricultural crops like rice, wheat and sugar cane are mostly consumed as fodder or used as raw material for paper industries, and less than $10 \%$ are available in surplus, which is also reliant on the weather due to the significant dependence of Indian agriculture on rainwater for irrigation. Biofuels provide about one-third of the total energy in developing countries, and up to $80 \%$ of energy in some sub-regions of Africa ${ }^{33}$, while biomass often accounts for more than $90 \%$ of total rural energy supplies in developing countries, including Bangladesh and India ${ }^{11}$, and biomass resources are utilized to an extreme and possibly dangerous extent $^{68}$. In Bangladesh, the household sector consumes $80 \%$ of total biomass energy and rural households use it almost exclusively for cooking. The combination of population growth with the decreasing per capita land area and growing energy needs puts great stress on the available biomass resources ${ }^{7}$, and requires judicious alteration of energy consumption patterns ${ }^{93}$. Despite afforestation/reforestation initiatives, the Earth's forest cover is dwindling in various parts of the world (especially in developing countries), because supply is outpaced by evergrowing demand. Therefore, it is hard to imagine how biofuels can be produced from lignocellulosic biomass in developing countries, meet rural energy demand in the form of biomass and avoid deforestation. Concerns over sustainability and perceptions about the negative impacts of biofuels in particular are growing and prompting clos- er scrutiny of policies designed to expand bioenergy use. A sustainable liquid biofuel program in developing countries may only be feasible if modern energy carriers replace the present inefficient biomass consumption in rural areas. Although there are several explanations for the contradictory results regarding the sustainability of biofuels, the socio-economic aspects concerning biofuel production and its rebound effects must be considered, especially in developing countries.

It is likely that biofuels from lignocellulosic biomass might be an alternative option to reduce GHG emissions and improve energy security in the developed countries where crop residues are known to be abundant, yet the main constraint is the ethanol production cost. The life cycle GHG emission of various forms of bioenergy and their ability to reduce GHG emissions vary widely, and are dependent on the land use changes, choice of feedstock, agricultural practices, refining and conversion process and finally the end use practices. GHG emissions may intensify still further if the forest land is cleared to make way for new energy crops ${ }^{127}$. Commercial biofuel production may target higher-quality lands, due to better profit margins and relegate cereals and subsistence crops to low-quality land which will have knockon effects on farm income, government payments and food prices. Hence, biofuel feedstock must be produced through biofuel plantations on agriculturally surplus/ marginal soils or degraded/desertified soils which do not compete with those dedicated to food crop production, in order to ease pressure on land used for food and feed and avoid any potential conflicts with food production.

Although lignocellulosic biomass is known to be highly reproducible and does not compete with foods, substantial doubts remain concerning the economic and environmental performance of biofuels ${ }^{92,104,124,138}$. The main bottleneck hampering the sustainability of lignocellulosic ethanol is its production cost. Wide variation was observed in both the reported cost of feedstock, enzymes and microorganisms, and fixed costs, which are dependent on the plant's life-span, yearly operating periods and regions, with the reported enzyme cost the most wideranging variable. It is also worth noting that most of those studies referred to the highly optimistic or futuristic enzyme cost reported by the NREL ${ }^{1,84,135}$, which may or may not be achievable depending on whether a biotechnological revolution takes place in this sector. In an effort to reduce the enzyme production cost, research activities have also been undertaken to identify alternate carbon sources instead of commercial cellulose ${ }^{57}$. It is also noted that the characteristics of electricity and biomass markets and fuel prices are crucial for the future of this sector ${ }^{12}$. The reviewed literature indicates that the 
biotechnological revolution is a must for the sustainability of bioethanol, especially in the fields of enzymes and microorganisms. In addition, strong renewable energy, an industrial policy to reduce fixed costs and an agriculture policy might be helpful in reducing feedstock costs, where agriculture is heavily government subsidized. Therefore, in-depth studies are required for each stage of the life cycle of bioethanol from lignocellulosic biomass, markets of bioenergy for any investment and commercial production.

\section{Conclusion}

This study revealed that environmental impacts and the production cost of bioethanol are dependent on feedstock, conversion technologies, system boundaries, allocation methods, the utilization of by-products and the end use characteristics. The reported hotspots reportedly vary among studies depending on the assumptions, system boundaries and impact categories employed. Although environmental benefits are reported in most studies, economic viability is doubtful with present technologies. Significant variation was observed in the reported production cost of bioethanol, especially enzyme cost. However, the biotechnological revolution is a must for the sustainability of this sector, especially in the field of enzymes and microorganisms. Extended national or international support may enable the prevailing hurdle in this sector to be overcome. In addition, the adaptation of innovative technologies and renewable energy policy (to reduce feedstock cost) may facilitate the production of economically viable bioethanol, especially from agri-residues where agriculture is heavily subsidized. If crop residues are employed in the bioethanol industry, there must be careful consideration of soil quality to avoid any productivity loss. Finally, the bioethanol industry must be vigorously evaluated using LCA methodologies for any investment and commercial production, and its sustainability.

\section{Acknowledgments}

This study was supported by a grant from the Ministry of Agriculture, Forestry and Fisheries of Japan (Rural Biomass Research Project, BEC-BA260-2).

\section{References}

1. Aden, A. et al. (2002) Lignocellulosic biomass to ethanol process design and economics utilizing co-current dilute acid prehydrolysis and enzymatic hydrolysis for corn stover. Golden, CO: National Renewable Energy Laboratory,
Report No. NREL/TP-510-32438. http://www.nrel.gov/ docs/fy02osti/32438.pdf.

2. Aden, A. (2008) Biochemical Production of Ethanol from Corn Stover: State of technology model. Golden, CO: National Renewable Energy Laboratory, Report No. NREL/TP510-43205. http://www.nrel.gov/docs/fy08osti/43205.pdf.

3. AEA Technology (2003) International resource costs of biodiesel and bioethanol. Department for Transport, Government of United Kingdom, London, UK.

4. Balat, M. (2011) Production of bioethanol from lignocellulosic materials via the biochemical pathway: A review. Energy Con. Manag., 52, 858-875.

5. Ballerini, D. et al. (1994) Ethanol production from lignocellulosics: Large scale experimentation and economics. Bioresour. Technol., 50, 17-23.

6. Banse, M. et al. (2011) Impact of EU biofuel policies on world agricultural production and land use. Biomass and Bioenergy, 35, 2385-2390.

7. Bari, M.N. et al. (1998) Biomass energy use at the household level in two villages of Bangladesh: Assessment of field methods. Biomass and Bioenergy, 15, 171-180.

8. Barta, Z., Reczey, K. \& Zacchi, G. (2010a) Techno-economic evaluation of stillage treatment with anaerobic digestion in a softwood-to-ethanol process. Biotechnol. Biofuels, 3, 21.

9. Barta, Z. et al. (2010b) Process design and economics of on-site cellulase production on various carbon sources in a softwood-based ethanol plant. Enzyme Research, Article ID734182.

10. Bennett, R. et al. (2004) Environmental and human health impacts of growing genetically modified herbicide-tolerant sugar beet: a life cycle assessment. Plant Biotechnol. J., 2, 272-278.

11. Bhattacharya, S.C., Abdul Salam, P. \& Sharma, M. (2000) Emission from biomass energy use in some selected Asian countries. Energy, 25, 169-188.

12. Blanco, B.I. \& Azqueta, D. (2008) Can the environmental benefits of biomass support agriculture?-The case of cereals for electricity and bioethanol production in Northern Spain. Energy Policy, 36, 357-366.

13. Blanco-Canqui, H. \& Lal, R. (2009) Corn stover removal for expanded uses reduces soil fertility and structural stability. Soil Sci. Soci. Am. J., 73, 418-426.

14. Blottnitz, H. V. \& Curran, M. A. (2007) A review of assessments conducted on bio-ethanol as a transportation fuel from a net energy, greenhouse gas, and environmental life cycle perspective. J. Clean. Prod., 15, 607-619.

15. Börjesson, P. \& Tufvesson, L.M. (2010) Agricultural cropbased biofuels-resource efficiency and environmental performance including direct land use changes. J. Clean. Prod., 19, 108-120.

16. Botha, T. \& Blottnitz, H. V. (2006) A comparison of the environmental benefits of bagasse-derived electricity and fuel ethanol on a life-cycle basis. Energy Policy, 34, 26542661.

17. Brandão, M., Canals, L.M. \& Clift, R. (2011) Soil organic carbon changes in the cultivation of energy crops: Implications for GHG balances and soil quality for use in LCA. Biomass and Bioenergy, 35, 2323-2336.

18. Brentrup, F. et al. (2004a) Environmental impact assessment of agricultural production systems using the life cycle 
assessment methodology: I. Theoretical concept of a LCA method tailored to crop production. Eur. J. Agron., 20, 247264.

19. Brentrup, F. et al. (2004b) Environmental impact assessment of agricultural production systems using the life cycle assessment (LCA) methodology: II. The application to N fertilizer use in winter wheat production systems. Eur. $J$. Agron., 20, 265-279.

20. Bryant, C. (2009) Step change in cellulosic ethanol-the future is moving closer. Brussels: World Biofuels Market (reported in $\left.{ }^{110}\right)$.

21. Campbell, J.E., Lobell, D.B. \& Field C.B. (2009) Greater transportation energy and GHG offsets from bioelectricity than ethanol. Science, 324, 1055-1057.

22. Cardona, C. A. \& Sa'nchez, O'. J. (2007) Fuel ethanol production: Process design trends and integration opportunities. Bioresour. Technol., 98, 2415-2457.

23. Cherubini, F. et al. (2009) Energy- and greenhouse gasbased LCA of biofuel and bioenergy systems: Key issues, ranges and recommendations. Resour. Cons. Recycl., 53, 434-447.

24. Cherubini, F. \& Strømman, A. H. (2011) Life cycle assessment of bioenergy systems: State of the art and future challenges. Bioresour. Technol., 102, 437-451.

25. Cherubini, F. \& Ulgiati, S. (2010) Crop residues as raw materials for biorefinery systems - A LCA case study. Appl. Energy, 87, 47-57.

26. Cherubini, F. \& Jungmeier, G. (2010) LCA of a biorefinery concept producing bioethanol, bioenergy, and chemicals from switchgrass. Int. J. Life Cycle Assess., 15, 53-66.

27. Colchester, M. et al. (2006) Promised land: Palm oil and land acquisition in Indonesia-Implications for local communities and indigenous peoples. Forest Peoples Programme, Perkumpulan Sawit Watch, Association for Community and Ecology-Based Law Reform (HuMA), and World Agroforestry Centre (ICRAF), Indonesia.

28. Colchester, M. et al. (2007) Land is life: Land rights and oil palm development in Sarawak. Forest Peoples Programme and Perkumpulan Sawit Watch, Indonesia.

29. Croezen, H. \& Kampman, B. (2009) The impact of ethanol and ETBE blending on refinery operations and GHG-emissions. Energy Policy, 37, 5226-5238.

30. Davis, S. C., Anderson-Teixeira, K. J. \& DeLucia, E. H. (2009) Life-cycle analysis and the ecology of biofuels. Trends Plant Sci., 14, 140-146.

31. Dutta, A. et al. (2010) An economic comparison of different fermentation configurations to convert corn stover to ethanol using Z. mobilis and Saccharomyces. Biotechnol. Prog. 26, 64-72.

32. Eggeman, T. \& Elander, R. (2005) Process and economic analysis of pretreatment technologies. Bioresour. Technol., 96, 2019-2025.

33. FAO (2008) Wood energy. http://www.fao.org/forestry/energy/en/.

34. Fargione, J. et al. (2008) Land clearing and the biofuel carbon debt. Science, 319, 1235-1238.

35. Farrell, A. E. et al. (2006) Ethanol can contribute to energy and environmental goals. Science, 311, 506-508.

36. Firbank, L.G. (2008) Assessing the Ecological Impacts of Bioenergy Projects. BioEnergy Res., 1, 12-19.

37. Fleming, J.S., Habibi, S. \& MacLean, H.L. (2006) Investi- gating the sustainability of lignocellulose-derived fuels for light-duty vehicles. Transport. Res. Part D: Transport and Environ., 11, 146-159.

38. Fu, G., Chan, A. \& Minns, D. (2003) Life cycle assessment of bio-ethanol derived from cellulose. Int. J. Life Cycle Assess., 8, 137-141.

39. Gabrielle, B. \& Gagnaire, N. (2008) Life-cycle assessment of straw use in bio-ethanol production: A case study based on biophysical modeling. Biomass and Bioenergy, 32, 431441.

40. Galbe, M, \& Zacchi, G. (2002) A review of the production of ethanol from softwood. Appl. Microbiol. Biotechnol., 59, 618-628.

41. Global Bioenergy Partnership (GBEP) (2009) The GBEP common methodological framework for GHG lifecycle analysis of bioenergy - Version Zero. http://www.globalbioenergy.org/fileadmin/user_upload/gbep/docs/2009 events/7th_SC_NY/GBEP GHG report 2306.pdf.

42. Gnansounou, E. (2010) Production and use of lignocellulosic bioethanol in Europe: Current situation and perspectives. Bioresour. Technol., 101, 4842-4850.

43. Gnansounou, E. \& Dauriat, A. (2010) Techno-economic analysis of lignocellulosic ethanol: A review. Bioresour. Technol., 101, 4980-4991.

44. González-García, S. et al. (2009) Life cycle assessment of flax shives derived second generation ethanol fueled automobiles in Spain. Renew. Sustain. Revs., 13, 1922-1933.

45. González-García, S. et al. (2010) Environmental profile of ethanol from poplar biomass as transport fuel in Southern Europe. Renewable Energy, 35, 1014-1023.

46. Graham, R. L. et al. (2007) Current and potential U.S. corn stover supplies. Agron. J., 99, 1-11.

47. Gray, K.A., Zhao, L.S. \& Emptage, M. (2006) Bioethanol. Curr. Opin. Chem. Biol., 10, 141-146.

48. Gregg, D.J., Boussaid, A. \& Saddler, J.N. (1989) Technoeconomic evaluations of a generic wood-to-ethanol process: effect of increased cellulose yields and enzyme recycle. Bioresour. Technol., 63, 7-12.

49. Guinée, J. B., Heijungs, R. \& Huppes, G. (2004) Economic allocation-examples and derived decision tree. Int. J. Life Cycle Assess., 9, 23-33.

50. Guo, Y. et al. (2010) Optimization and analysis of a bioethanol agro-industrial system from sweet sorghum. Renewable Energy, 35, 2902-2909.

51. Haas, G., Wetterich, F. \& Köpke, U. (2001) Comparing intensive, extensified and organic grassland farming in southern Germany by process life cycle assessment. Agri. Ecosys. Environ., 83, 43-53.

52. Hägerdal, H.B. et al. (2006) Bioethanol-the fuel of tomorrow from the residues of today. Trends in Biotechnol., 24, 549-556.

53. Hamelinck, C.N., Hooijdonk, G.V. \& Faaij, A.P.C. (2005) Ethanol from lignocellulosic biomass: techno-economic performance in short-, middle- and long-term. Biomass and Bioenergy, 28, 384-410.

54. Haney, R.L., Kiniry, J.R. \& Johnson, M.V.V. (2010) Soil microbial activity under different grass species: Underground impacts of biofuel cropping. Agri. Ecosys. Environ., 139, 754-758.

55. Hatti-Kaul1, R. et al. (2007) Industrial biotechnology for the production of bio-based chemicals - a cradle-to-grave 
perspective. Trends in Biotechnol., 25, 119-124.

56. He, J. \& Zhang, W. (2011) Techno-economic evaluation of thermo-chemical biomass-to-ethanol. Appl. Energy, 88, 1224-1232.

57. Hideno, et al. (2011) Production and characterization of cellulases and hemicellulases by Acremonium cellulolyticus using rice straw subjected to various pretreatments as the carbon source. Enzyme and Microb. Technol., 48, 162-168.

58. Huang, H.J. et al. (2009) Effect of biomass species and plant size on cellulosic ethanol: A comparative process and economic analysis. Biomass and Bioenergy, 33, 234-246.

59. ISO (International Organization for Standardization) (1997) ISO 14040 Environmental management—Life cycle assessment-Principles and framework.

60. ISO (International Organization for Standardization) (2006) ISO 14040: 2006(E) Environmental management - Life cycle assessment —Principles and framework.

61. Jenkinsoin, D.S. \& Ayanaba, A. (1977) Decomposition of the $\mathrm{C}$ labeled plant material under tropical conditions. Soil Sci. Soci. Am. J., 41, 912-915.

62. Jensen, J. R., Halvorsen, K. E. \& Shonnard, D. R. (2010) Ethanol from lignocellulosics, U.S. federal energy and agricultural policy, and the diffusion of innovation. Biomass and Bioenergy, 35, 1440-1453.

63. Johnson, E. (2009) Goodbye to carbon neutral: Getting biomass footprints right. Environ. Impact Assess. Rev., 29, 165-168.

64. Johnson, J. (2006) Minimum C inputs and sustainability of biomass harvest. http://crops.confex.com/crops/2006am/ techprogram/P20045.HTM.

65. Jolliet, O. et al. (2004) The LCIA midpoint-damage framework of the UNEP/SETAC life cycle initiative. Int. J. Life Cycle Assess., 9, 394-404.

66. Jungbluth, N. et al. (2005) Life cycle assessment for emerging technologies: case studies for photovoltaic and wind power. Int. J. Life Cycle Assess., 10, 24-34.

67. Kaufman, A. S. et al. (2010) Applying life-cycle assessment to low carbon fuel standards-How allocation choices influence carbon intensity for renewable transportation fuels. Energy Policy, 38, 5229-5241.

68. Kennes, W., Parik, J.K. \& Stolwisk, H. (1984) Energy from biomass by socio-economic groups? A case study of Bangladesh. Biomass, 4, 209-234.

69. Kim, S. \& Dale, B.E. (2002) Allocation procedure in ethanol production system from corn grain I. System expansion. Int. J. Life Cycle Assess., 7, 237-243.

70. Kim, S. \& Dale, B. E. (2005) Life cycle assessment of various cropping systems utilized for producing biofuels: bioethanol and biodiesel. Biomass and Bioenergy, 29, 426439.

71. Kim, S., Dale, B.E. \& Jenkins, R. (2009) Life cycle assessment of corn grain and corn stover in the United States. Int. J. Life Cycle Assess., 14, 160-174.

72. Klein-Marcuschamer, D. et al. (2010) Technoeconomic analysis of biofuels: A wiki-based platform for lignocellulosic biorefineries. Biomass and Bioenergy, 34, 1914-1921.

73. Koga, N. \& Tajima, R. (2011) Assessing energy efficiencies and greenhouse gas emissions under bioethanol-oriented paddy rice production in northern Japan. J. Environ. Manag., 92, 967-973.

74. Kou, N. \& Zhao, F. (2010) Effect of multiple-feedstock strategy on the economic and environmental performance of thermochemical ethanol production under extreme weather conditions. Biomass and Bioenergy, 35, 608-616.

75. Kusiima, J. M. \& Powers, S. E. (2010) Monetary value of the environmental and health externalities associated with production of ethanol from biomass feedstocks. Energy Policy, 38, 2785-2796.

76. Liebig, M. A. et al. (2005) Soil carbon under switchgrass stands and cultivated cropland. Biomass and Bioenergy, 28, 347-354.

77. Luo, L., van der Voet, E. \& Huppes, G. (2009a) An energy analysis of ethanol from cellulosic feedstock-corn stover. Renew. Sustain. Rev., 13, 2003-2011.

78. Luo, L. et al. (2009b) Allocation issues in LCA methodology: a case study of corn stover-based fuel ethanol. Int. J. Life Cycle Assess., 14, 529-539.

79. Luo, L., van der Voet, E. \& Huppes, G. (2010) Biorefining of lignocellulosic feedstock - Technical, economic and environmental considerations. Bioresour. Technol., 101, 5023-5032.

80. Lynd, L.R. et al. (2002) Microbial cellulose utilization: fundamentals and biotechnology. Microbiol. Mol. Biol. Rev., 66, 506-577.

81. Mabee, W. E. \& Saddler, J. N. (2010) Bioethanol from lignocellulosics: Status and perspectives in Canada. Bioresour. Technol., 101, 4806-4813.

82. Mabee, W. E. et al. (2006) Update on softwood-to-ethanol process development. Appl. Biochem. Biotechnol, 129, 5570.

83. Margeot, A. et al. (2009) New improvements for lignocellulosic ethanol. Curr. Opin. Biotechnol. 20, 372-380.

84. McAloon, A. et al. (2000) Determining the cost of producing ethanol from corn starch and lignocellulosic feedstocks, National Renewable Energy Laboratory, Golden, CO, NREL/TP-580-28893.

85. Mclaughlin, S.B. et al. (2002) High-value renewable energy from prairie grasses. Environ. Sci. Technol., 36: 21222129.

86. Monti, A., Fazio, S. \& Venturi, G. (2009) Cradle-to-farm gate life cycle assessment in perennial energy crops. Eur. J. Agron., 31, 77-84.

87. Nelson, R. (2002) Resource assessment and removal analysis for corn stover and wheat straw in the eastern and Midwestern United States: Rainfall and wind erosion methodology. Biomass and Bioenergy, 22, 349-363.

88. Nigam, P.S. \& Singh, A. (2011) Production of liquid biofuels from renewable resources. Prog. Energy Comb. Sci., 37, 52-68.

89. Orikasa, T. et al. (2009) Effect of ethanol conversion efficiency on cost, $\mathrm{CO}_{2}$ emission and energy balance in the bioethanol production system from rice straw. J. Jpn. Soci. Agril. Machinery, 71, 45-53.

90. Pedersen, J.F., Vogel, K.P. \& Funnell, D. (2005) Impact of reduced lignin on plant fitness. Crop $S c i$., 45, 812-819.

91. Pickett, J. et al. (2008) Sustainable biofuels: Prospects and challenges (The Royal Society, London, 2008).

92. Pimentel, D. \& Patzek, T. W. (2005) Ethanol production using corn, switchgrass, and wood; biodiesel production using soybean and sunflower. Nat. Resour. Res., 14, 65-76.

93. Pokharel, S., Chandrashekar, M. \& Robinson, J. B. (1992) Interfuel and intermode substitution for cooking. Energy, 
17, 907-918.

94. Reijnders, L. (2008) Ethanol production from crop residues and soil organic carbon. Resour. Cons. Recycl., 52, 653658.

95. Reith, J. H. et al. (2002) Co-production of bio-ethanol, electricity and heat from biomass residues. The $12^{\text {th }}$ European Conference and Technology Exhibition on Biomass for Energy, Industry and Climate Protection, Amsterdam, The Netherlands, June 17-21.

96. Roy, P. et al. (2010) Evaluation of the life cycle of bioethanol produced from rice straw by enzymatic hydrolysis process. The Proceeding of the $9^{\text {th }}$ International Conference on EcoBalance, Tokyo, Japan, November 9-12.

97. S\&T2 (2004) Economic, financial, social analysis and public policies for fuel ethanol. S\&T2 Consultants Inc., Canada.

98. Saga, K. et al. (2010) Net energy analysis of bioethanol production system from high-yield rice plant in Japan. Appl. Energy, 87, 2164-2168.

99. Sánchez, O'. J. \& Cardona, C. A. (2008) Trends in biotechnological production of fuel ethanol from different feedstocks. Bioresour. Technol., 99, 5270-5295.

100. Sassner, P. \& Zacchi, G. (2008) Integration options for high energy efficiency and improved economics in a wood-toethanol process. Biotechnol. Biofuels, 1, 4.

101.Sassner, P., Galbe, M. \& Zacchi, G. (2008) Techno-economic evaluation of bioethanol production from three different lignocellulosic materials. Biomass and Bioenergy, 32, 422-430.

102. Schmer, M. R. et al. (2008) Net energy of cellulosic ethanol from switchgrass. Proc. Natl. Acad. Sci. USA, 105, 464469.

103. Seabra, J.E.A. et al. (2010) A techno-economic evaluation of the effects of centralized cellulosic ethanol and co-products refinery options with sugarcane mill clustering. Biomass and Bioenergy, 34, 1065-1078.

104. Searchinger, T. et al. (2008) Use of U.S. croplands for biofuels increases greenhouse gases through emissions from land-use change. Science, 319, 1238-1240.

105. Searcy, E. \& Flynn, P. C. (2010) A criterion for selecting renewable energy processes. Biomass and Bioenergy, 34, 798-804.

106. Searcy, E. \& Flynn, P.C. (2008) Processing of straw/corn stover: comparison of life cycle emissions. Int. J. Green Energy, 5, 423-437.

107. Service, R. F. (2010) Scaling up alternative energy: Is there a road ahead for cellulosic ethanol? Science, 329, 784-785.

108. Sheehan, J. et al. (2003) Energy and environmental aspects of using corn stover for fuel ethanol. J. Ind. Ecol., 7, 117146.

109. Sheehan, J. et al. (2002) Is ethanol from corn stover sustainable? Adventures in cyber-farming: a life cycle assessment of the production of ethanol from corn stover for use in a flex fuel vehicle. Draft report for peer review, Colorado, NREL.

110.Sims, R. E. H. et al. (2006) Energy crops: current status and future prospects. Global Change Biol., 12, 2054-2076.

111. Singh, A. et al. (2010) Key issues in life cycle assessment of ethanol production from lignocellulosic biomass: Challenges and perspectives. Bioresour. Technol., 101, 50035012 .
112. Singh, S. \& Kumar, A. (2010) Development of water requirement factors for biomass conversion pathway. Bioresour. Technol., 102, 1316-1328.

113. Slade, R., Bauen, A. \& Shah, N. (2009a) The greenhouse gas emissions performance of cellulosic ethanol supply chains in Europe. Biotechnol. Biofuels, 2, 15.

114. Slade, R., Bauen, A. \& Shah, N. (2009b) The commercial performance of cellulosic ethanol supply-chains in Europe. Biotechnol. Biofuels, 2, 3.

115.Spatari, S., Zhang, Y. \& MacLean, H.L. (2005) Life cycle assessment of switchgrass- and corn stover-derived ethanol-fueled automobiles. Environ. Sci. Technol., 39, 97509758.

116. Spatari, S., Bagley, D.M. \& MacLean, H.L. (2010) Life cycle evaluation of emerging lignocellulosic ethanol conversion technologies. Bioresour. Technol., 101, 654-667.

117. Stephenson, A.L. et al. (2010) The environmental and economic sustainability of potential bioethanol from willow in the UK. Bioresour. Technol., 101, 9612-9623.

118. Stoeglehner, G. \& Narodoslawsky, M. (2009) How sustainable are biofuels? Answers and further questions arising from an ecological footprint perspective. Bioresour. Technol., 100, 3825-3830.

119. Stolman, M. (2005) Ethanol and the net energy debate. www.e2.org/ext/jsp/controller?docId $=8461$.

120. Sukumaran, R.K. et al. (2010) Lignocellulosic ethanol in India: Prospects, challenges and feedstock availability. Bioresour. Technol., 101, 4826-4833.

121. Swana, J. et al. (2010) An analysis of net energy production and feedstock availability for biobutanol and bioethanol. Bioresour. Technol., 102, 2112-2117.

122.Tan, K. T., Lee, K. T. \& Mohamed, A. R. (2008) Role of energy policy in renewable energy accomplishment: The case of second-generation bioethanol. Energy Policy, 36, 33603365 .

123. Tilman, D., Hill, J. \& Lehman, C. (2006) Carbon-negative biofuels from low-input high-diversity grassland biomass. Science, 314, 1598-1600.

124. Tilman, D. et al. (2009) Beneficial biofuels the food, energy, and environment trilemma. Science, 325, 270-271.

125. Tyndall, J.C., Berg, E. J. \& Colletti, J. P. (2010) Corn stover as a biofuel feedstock in Iowa's bio-economy: An Iowa farmer survey. Biomass and Bioenergy, 35, 1485-1495.

126.Uihlein, A. \& Schebek, L. (2009) Environmental impacts of a lignocellulose feedstock biorefinery system: an assessment. Biomass and Bioenergy, 33, 793-802.

127.UN Energy (2007) Sustainable bioenergy: A framework for decision makers. http://esa.un.org/un-energy/pdf/susdev.Biofuels.FAO.pdf.

128.Vadas, P.A., Barnett, K.H. \& Undersander, D. J. (2008) Economics and energy of ethanol production from alfalfa, corn and switchgrass in the upper Midwest, USA. J. Bioen. Res., 1, 44-55.

129. Velásquez-Arredondo, H. I., Ruiz-Colorado, A. A. \& Oliveira Junior, S. D. (2010) Ethanol production process from banana fruit and its lignocellulosic residues: Energy analysis. Energy, 35, 3081-3087.

130.Vliet, V.O.P.R., Faaij, A.P.C. \& Turkenburg, W.C. (2009) Fischer-Tropsch diesel production in a well-to-wheel perspective: a carbon, energy flow and cost analysis. Energy Con. Manag., 50, 855-876. 
131.Wilhelm, W. W. et al. (2007) Corn stover to sustain soil organic carbon further constrains biomass supply. Agron. J., 99, 1665-1667.

132. Williams, P. R. D. et al. (2009) Environmental and sustainability factors associated with next-generation biofuels in the US: what do we really know. Environ. Sci. Technol., 43, 4763-4775.

133. Wingren, A., Galbe, M. \& Zacchi, G. (2003) Techno-economic evaluation of producing ethanol from softwood: comparison of SSF and SHF and identification of bottlenecks. Biotechnol. Prog., 19, 1109-1117.

134. Woods, J. (2006) Science and technology options for harnessing bioenergy's potential. IFPRI, Washington DC, USA.

135. Wooley, R. et al. (1999) Lignocellulosic biomass to ethanol-process design and economics utilizing co-current dilute acid prehydrolysis and enzymatic hydrolysis - current and futuristic scenarios, Report No. TP-580-26157. National Renewable Energy Laboratory. Golden Colorado, USA.

136. Wu, M., Wu, Y. \& Wang, M. (2008) Mobility chain analy- sis of technologies for passenger cars and light-duty vehicles fueled with biofuels: Application of the GREET Model to the role of biomass in America's Energy Future (RBAEF) Project. Center for Transportation Research, Energy Systems Division, Argonne National Laboratory, http://www.osti.gov/bridge

137.Wyman, C. E. (1994) Ethanol from lignocellulosic biomass: technology, economics, and opportunities. Bioresour. Technol., 50, 3-15.

138. Wyman, C.E. (2007) What is (and is not) vital to advancing cellulosic ethanol. Trends in Biotechnol., 25, 153-157.

139. Yamamoto, H., Fujino, J. \& Yamaji, K. (2001) Evaluation of bioenergy potential with a multi-regional global-land-useand-energy model. Biomass and Bioenergy, 21, 185-203.

140.Zah, R. et al. (2007) Life cycle assessment of energy products: Environmental assessment of biofuels, EMPA, Bern, Switzerland. www.empa.ch/tsl.

141.Zaldivar, J., Nielsen, J. \& Olsson, L. (2001) Fuel ethanol production from lignocellulose: a challenge for metabolic engineering and process integration. Appl. Microbiol. Biotechnol., 56, 17-34. 